\title{
Integration with Secondary Stakeholders and Its Relationship with Sustainable Supply Chain Practices in Colombian SMES
}

\author{
Laura M. Quiroga-Calderón ${ }^{1}$, Ismael S. Mejía-Salazar ${ }^{2}$, \\ Carlos E. Moreno-Mantilla ${ }^{3}$, Juan P. Loaiza-Ramírez ${ }^{1}$
}

\begin{abstract}
The study of the relationship between the integration of Small and Medium-sized Enterprises (SMEs) with external stakeholders (e.g., NGOs, academia, the regulator, or communities) and the implementation of green and social practices in SMEs' supply chains has received little attention in the literature. Hence, this research studies whether Green Supply Chain Management (GSCM) practices and more disruptive innovations involving the redefinition of the supply chain's strategy are influenced by firms' integration with this type of stakeholders. A survey questionnaire with 50 items drawn from the literature was applied to a convenience sample of Colombian SMEs. Experts previously evaluated a pilot instrument in terms of face validity, and then a survey pretest was conducted. Lineal regression analysis was performed on single scores computed for latent variables validated through factor analysis. Results show that the integration between SMEs and the community influences both GSCM and disruptive practices, and there is also some evidence for the positive effect on the latter originated in the integration with NGOs. Finally, there is no evidence that integration with the regulator influences either the development of GSCM practices or disruptive innovations.
\end{abstract}

Keywords: Sustainability, stakeholder integration, SMEs, environmental innovation, social sustainability, sustainable supply chain

\section{Introduction}

Currently, environmental and social issues have become great challenges for regulators, companies and civil organizations (Tamayo Orbegozo, Vicente Molina, \& Villarreal Larrinaga, 2016). This situation has increased the interest of societal actors in the adoption and implementation of Green Supply Chain Management (GSCM) practices as a way to achieve sustainable development (Testa \& Iraldo, 2010). Likewise, socially- and environmentally-oriented innovation has become a well-studied and applied field (Klewitz \& Hansen, 2014). Initially, companies were considered as the main polluting agents but, thanks to environmental management and eco-innovation, they have become a fundamental part of the solution to these problems (Aragón Correa, Hurtado Torres, \& García Morales, 2005). In research, the number of studies about environmental and social supply chain management has increased, as well as the aspects related, e.g. determining factors, performance outcomes, relationships with firm stakeholders, etcetera (Chen et al., 2017; Diabat, Kannan, \& Mathiyazhagan, 2014;

\footnotetext{
$\mid{ }^{1}$ Master student in Industrial Engineering, at Universidad Nacional de Colombia in Bogotá.

${ }^{2} \mathrm{PhD}$ student in Engineering - Industry and Organizations at Universidad Nacional de Colombia in Bogotá.

${ }^{3}$ Associate Professor, Department of Systems and Industrial Engineering at Universidad Nacional de Colombia in Bogotá.
} 
Schöggl, Fritz, \& Baumgartner, 2016; Seuring \& Müller, 2008).

However, many of these studies have focused on large companies, without considering the importance of Small and Medium-sized Enterprises (SMEs) in sustainable development. These companies correspond to about $90 \%$ of the total industry and contribute to around 50\% of pollution (Aragón Correa et al., 2005). Some authors argue that SMEs do not engage in eco-innovative practices for different reasons, such as low management skills, dependency on people to survive, limited technology and lack of financial resources required for knowledge update (Bos-Brouwers, 2010). In contrast, other authors argue that smaller firms are in a better position than larger ones to innovate radically and compete in sustainable market niches (Schaltegger \& Wagner, 2011).

Nevertheless, SMEs innovate differently, and they may encounter advantages for innovation in features such as their entrepreneurial style, a simple and flexible organizational structure led by its owner or manager, shared vision, stakeholder management and strategic proactivity (Aragón-Correa, Hurtado-Torres, Sharma, \& García-Morales, 2008). Finally, SMEs can become focal companies for GSCM or Sustainable Supply Chain Management (SSCM) (Carter \& Rogers, 2008; Gold, Seuring, \& Beske, 2010; Seuring \& Müller, 2008) by achieving sustainability-oriented innovations (Klewitz \& Hansen, 2014).

In most cases, GSCM practices are adopted by "follower" SMEs as a response to consumer and client pressures or induced from other supply chain members that have started a GSCM initiative (i.e., "leaders" or "focal" companies) (Testa \& Iraldo, 2010). However, when SMEs participate actively in a collaboration network, either with members of the supply chain, regulators, academia or NGOs, they can obtain different benefits such as motivation, technological support, donations, free consulting, and others (Aragón-Correa, Hurtado-Torres, Sharma, \& García-Morales, 2008; Bianchi, 1998; BosBrouwers, 2010a; Klewitz \& Hansen, 2014a; Lawrence, Collins, Pavlovich, \& Arunachalam, 2006; Moreno-Mantilla, 2007; Rodgers, 2010; Rondinelli \& London, 2003).

In this sense, supply chain collaboration has become a key relational capability that facilitates strategic formulation and execution of environmental practices in the chain (Chin, Tat, \& Sulaiman, 2015; Gunasekaran, Subramanian, \& Rahman, 2015). At the same time, it promotes mutual learning, developing relations between government, companies and their supply chain partners, and favoring the solution to pressing environmental problems (Chin, Tat, \& Sulaiman, 2015).

For these reasons, stakeholders are relevant as drivers of the environmental proactive behavior of companies (Neelam, Suresh, \& Sharma, 2014). However, stakeholders do not have the same importance or exert the same pressure on companies (Betts, Wiengarten, \& Tadisina, 2015; Delmas \& Toffel, 2004). On the one hand, internal stakeholders (e.g. operational employees, administrative employees and shareholders) exert a greater impact on internal environmental management (Betts, Wiengarten, \& Tadisina, 2015; Ni, 2012). On the other hand, there are external actors which are subdivided into primary stakeholders, i.e. commercial buyers, consumers, suppliers, competitors (Neelam et al., 2014), and secondary stakeholders, such as environmental groups, community leaders, non-governmental organizations (NGOs), media and 
regulators (Delmas, 2009).

Secondary external actors are characterized by their lack of control over the critical resources of the organization (Buysse \& Verbeke, 2003; Ni, 2012). However, they have a great influence on the companies' environmental behavior, because they play an important and positive role to obtain competitive advantages (Delmas, 2009). So, according to Sharma and Vredenburg (1998), the firm should have "the ability to establish trust-based collaborative relationships with a wide variety of stakeholders, especially those with non-economic goals" (Aragón-Correa, Hurtado-Torres, Sharma, \& García-Morales, 2008; Sharma \& Vredenburg, 1998).

Yet, many companies have not treated with equal validity the claims of stakeholders without an economic stake in the chain (Pagell \& Shevchenko, 2014). In addition, it is often difficult to identify which secondary stakeholders are likely to play a role in the success of radical innovation (Fliaster \& Kolloch, 2017; Pagell \& Shevchenko, 2014). However, past empirical studies revealed the importance of advocacy groups (e.g. proenvironmental, anti-globalization, pro-safety, etc.), intergovernmental organizations, as well as local residents associations, property owners, or citizen action committees, among other (Fliaster \& Kolloch, 2017). Therefore, this research aims to understand whether the integration of Colombian SMEs with external secondary stakeholders influences the implementation of environmental and social practices in the supply chain. By answering this question, we can extend our knowledge of the process of adopting GSCM practices in SMEs, particularly in the context of an emerging economy such as the Colombian.

The following section of this article corresponds to the literature review and the research questions. Then, the methods section details the data and sampling procedure, the operationalization of the variables of the study through a survey questionnaire, and data analysis techniques. The article continues with the main findings and a discussion of the results, and ends with the conclusions and suggestions for future studies.

\section{Theory Framework}

According to de Lange (2010), the Resource-Based View (RBV) of the firm and stakeholder theory are two of the most used theories to study sustainability in organizations. Likewise, according to some authors, these theories are frequently used in theoretical articles related to SSCM (de Lange, 2010; Touboulic, Walker, Barlow, \& Pettigrew, 2011). In accordance to this, we have found that the guiding framework offered by these theories for the purposes of the present study is relevant, along with complementary insights from the GSCM (Srivastava, 2007) and sustainable innovation in SMEs (Klewitz \& Hansen, 2014) literatures.

Drawing from the RBV, Hart (1995) explains competitive advantages obtained from an improved environmental performance. The so-called Natural Resource-Based View (NRBV) proposes three key strategic environmental capabilities: pollution prevention, product stewardship and sustainable development. Each of these strategies is a source of competitive advantages and is based on various key resources (Hart \& Dowell, 2011). The main objective of pollution prevention is emission and waste reductions, and it is supported by the key resource of "continuous improvement" (Hart, 1995). Product stewardship is located in a second level; its driving force is the reduction of 
environmental costs and impacts throughout the life cycle product and its key resource is "stakeholder integration" (Betts, Wiengarten, \& Tadisina, 2015; Hart, 1995). Finally, the third level in this triad corresponds to sustainable development, which seeks to reduce the environmental burden from business growth and development (Betts et al., 2015). Hart \& Dowell (2011) have subdivided the latter into two related capabilities: clean technologies and base of pyramid.

In connection with our study, the evaluation of the extent of implementation of product stewardship practices seem relevant, as these refer to environmental practices displayed at the supply chain level that can also be traced back in the GSCM literature. For companies, this suggests taking an environmentally proactive stance, directed upstream to suppliers and downstream to customers, in order to minimize the environmental impact of the entire supply system and improve its performance (Buysse \& Verbeke, 2003; Hart, 1995; Vachon \& Klassen, 2008). Beyond practice, for research there is the implication that GSCM practices have an antecedent in the strategic resource of stakeholder integration, as posed by Hart (1995) in the NRBV.

GSCM can be defined as the incorporation of environmental thinking in Supply Chain Management (SCM) (Gandhi, Mangla, Kumar, \& Kumar, 2015), through the development of practices that encompass both internal and external activities (Vachon \& Klassen, 2006). Furthermore, GSCM takes into account the entire life cycle of the product, from its design (eco-design), selection and supply of materials (green purchases), its manufacture, delivery to consumers (green distribution), and end of life management (reverse logistics) (Gandhi, Mangla, Kumar, \& Kumar, 2015; Zhu, Sarkis, \& Lai, 2008).

Implementation of environmental practices in SCM can be motivated by internal or external factors (Testa \& Iraldo, 2010). For example, cognitive pressures such as customer requirements encourage companies to behave based on cultural affinity. In contrast, regulators exert coercive pressures through strict environmental standards, imposing sanctions/fines for non-compliance or requirements to publicly disclose information on the environmental impact of the organization (Testa \& Iraldo, 2010). Another example is the normative pressure exerted by community and environmental stakeholders, which motivate companies to carry out these strategies in order to earn social legitimacy and improve their reputation (Testa \& Iraldo, 2010).

However, beyond the drive for action, the cooperation with other actors in the supply chain increases the ability of firms to continuously pursue sustainability-oriented innovations (Gandhi, Mangla, Kumar, \& Kumar, 2015). From the point of view of innovation theory, eco-innovation is defined as the production, application or exploration of goods, services, processes, corporate methods, organizational or management structures, new or significantly improved, for the firm and/or consumer, which allows to achieve the reduction of environmental risks, pollution and negative impacts caused by the use of resources (de Jesus Pacheco et al., 2016; Hojnik \& Ruzzier, 2016). That is, eco-innovation encompass all changes, radical or incremental, that address sustainability objectives such as waste management, eco-efficiency, emission reduction, recycling and eco-design (Cainelli, De Marchi, \& Grandinetti, 2015).

According to Schumpeter (1942), large companies are more innovative, while small companies are less likely to achieve environmental innovations (del Brío \& Junquera, 
2003), due to financial and human resources limitations (Mir \& Feitelson, 2007), and the lack of adequate strategic management (Gerstenfeld \& Roberts, 2000). However, another strand of research emphasizes on the innovation facilitators found in SMEs. For example, smaller firms have a business style with simpler organizational structures (BosBrouwers, 2010b; Darnall, Henriques, \& Sadorsky, 2010), they are dominated by their owner-managers, and therefore can be strongly driven by value (Knight \& Jenkins, 2009). In addition, SMEs usually have more capacity for adapting to environmental changes (Sroufe, Curkovic, Montabon, \& Melnyk, 2000).

Stakeholder Theory defines stakeholders as those individuals or groups that exert influence or can be affected by the organizational reach (Mainardes, Alves, \& Raposo, 2011). In environmental management, stakeholders are drivers of environmentally proactive behavior (Neelam et al., 2014). Secondary external actors do not have control over the critical resources of the organization; however, collaboration with stakeholders such as the regulator and environmental NGOs seems crucial in the construction of environmental standards or norms, as well as in the establishment of voluntary agreements (Buysse \& Verbeke, 2003). Collaboration with the regulator, NGOs, clients and suppliers seem effective to improve the environmental performance of a company (Albino, Maria, \& Pontrandolfo, 2012).

Regarding collaboration with NGOs, Oelze et. al (2016) suggested that this is crucial for organizational learning. According to Rodriguez and Wiengarten (2017), NGOs can implement supplier development programs to attack sustainability challenges. In terms of supplier development for sustainability, Liu et al. (2018) propose that mutual involvement and changing roles can be achieved through strategic collaboration, adaptive management or organizational learning of both buying firms and NGOs.

Another important secondary actor is the academy. This actor has not been widely studied, but its role as a driver for the adoption of an environmental focus in companies R\&D and human capital training is well known (Khalili, Duecker, Ashton, \& Chavez, 2015). Rodriguez \& Wiengarten (2017) found that knowledge brought through Research and Development $(\mathrm{R} \& \mathrm{D})$ cooperation from public research institutions has a positive significant direct effect on environmental innovativeness capability. Other previous research found that $\mathrm{R} \& \mathrm{D}$ cooperation with universities enhances environmental innovation (De Marchi, 2012; Ghisetti \& Pontoni, 2015).

Perkmann and Walsh (2007) suggest that there are several interaction channels between universities and firms. They can undertake research projects together, e.g. consulting, contract research transactions, set human resource transfer programs between organizations, etc. (Perkmann \& Walsh, 2007). However, this type of collaboration is prone to show their effects in the medium or long term (Albino et al., 2012). From another perspective, Klewitz et al. (2012) theorize that collaboration networks with research institutes, agencies and universities are essential to activate all kinds of ecoinnovation in SMEs. These initiatives can improve the SMEs' organizational learning and their absorption capacity.

Another type of external stakeholder is society in general. These stakeholders include environmental groups, the community, the media and the syndicates, but are not limited to them. Each of these groups can mobilize public opinion in favor or against (Eesley \& Lenox, 2006). Henriquez and Sadorsky (1999) evaluated the perceived importance of 
different groups of stakeholders and found that the regulator, primary consumers, shareholders and the local community affect corporate environmental management practices, especially the contents of environmental action plans.

In conclusion, stakeholder theory has emphasized the importance of key stakeholders, their claims and an analysis of their interests. From the GSCM and NRBV perspectives, several authors have found that in order to move towards product stewardship, the company must not only coordinate their activities with supply chain actors, but also to integrate the perspectives of key external stakeholders, such as environmentalists, community leaders and regulators (Betts, Wiengarten, \& Tadisina, 2015; Hirsch-Hadorn, Bradley, Pohl, Rist \& Wiesmann, 2006, Darnall, Henriques, \& Sadorsky, 2010; Neelam, Suresh, \& Sharma, 2014; Ni, 2012).

Other authors have gone further and suggested that an adequate collaboration with nontraditional stakeholders in the innovation process can lead to radical innovations and new business models (Hart \& Sharma, 2004; Klewitz \& Hansen, 2014; Parrish \& Foxon, 2006). Hart and Sharma (2004, p. 13) theorized that the identification of business contexts that "are the reverse of those in which the business currently operates" (e.g., communities affected by pressing social issues such as population growth, lack of education or lack of vital public services) can generate imagination and ideas about potential new product and business innovations.

Based on the previous introduction and literature review, we propose the following research questions: Does stakeholder integration influence the extent of implementation of GSCM practices in Colombian SMEs? Does stakeholder integration influence the extent of implementation of sustainable innovations of a more disruptive nature in Colombian SMEs?

\section{Methods}

\subsection{Sampling and Data}

Based on the research framework and the research questions, the data collection follows a web survey strategy. The questionnaire targeted SMEs' managers, selected by convenience non-probabilistic sampling (Creswell, 2005), following two general criteria: company origin (only Colombian), and company size (between 11 to 200 employees, according to Colombian law). A 52-item questionnaire operationalizes three theoretical dimensions: GSCM practices (Green Jr, Zelbst, Meacham, \& Bhadauria, 2012; Vachon \& Klassen, 2008), advanced sustainable practices (Marshall, McCarthy, Heavey, \& McGrath, 2014), and stakeholder integration (Plaza-Úbeda, de Burgos-Jiménez, \& Carmona-Moreno, 2010). The questionnaire was pre-evaluated by academic and industry experts, in order to verify content validity (Imle \& Atwood, 1988; Polit, Beck, \& Owen, 2007). Then, the resulting questionnaire was pre-tested (Forza, 2002; Imle \& Atwood, 1988) by a first sample of SMEs, which was obtained from the Colombian Exporting SMEs Directory, 2017. From this, the items were reduced from 65 to the 51 that were finally used in the study.

Before applying the questionnaire, a "theoretical population" was defined (Trochim, 1999). This included Colombian SMEs that are involved in knowledge transfer with a public or private organization. Next, a "sampling frame" was delimited with the aid of the National Association of Industrial, Administrative and Production Engineering 
Students -ANEIAP by its Spanish initials. This Association gave us data from 1300 Colombian SMEs, which have employed practitioners or graduates of ANEIAP and or have been part of programs where knowledge is transferred. The previous sampling frame met the "completeness and accuracy" criteria typically demanded in sampling selection, because all these SMEs have the inter-organizational knowledge transfer element in common.

The response rate was $7.3 \%$. A total of 95 firms provided valid answers: 58 (61.05\%) with a number of employees between 11 and 50, classified as small firms, and 37 (38.95\%) medium size firms, which employ between 51 and 200 employees. 37 firms out of the total $(38.95 \%)$ belong to the manufacturing sector, 41 firms $(43.16 \%)$ to the service sector, and the 17 remaining $(17.89 \%)$ belong to other activities.

\subsection{Variables}

\section{a. Stakeholder Integration (STK_INTEG)}

This latent (i.e., non-observable) variable assesses the frequency of implementation of integration practices or routines between SMEs and a secondary key stakeholder, selected among four options: community, NGOs, academia, or regulator. This variable consists of three dimensions: knowledge of stakeholders (KNOW_STK), operationalized by 4 items (i.e., observed variables); interaction between stakeholder and the company (INT_STK), with 7 items; and adaptive behavior (ADAP_STK), with 4 observed variables (Plaza-Úbeda et al., 2010). We used a fivepoint Likert scale, where $1=$ Never, $2=$ Rarely, $3=$ Sometimes, $4=$ Often, $5=$ Always (Vagias, 2006).

b. GSCM Practices (GSCM_PRAC)

This variable aims to evaluate the frequency of implementation of GSCM practices, considering four dimensions: internal environmental management (IEM_SME), composed by 6 items; ecodesign (ED_SME), with 5 items; green purchasing and supply collaboration (GPURC_SME), with 7 items; and collaboration with clients (CLIEN_SME), with 7 items. As in the previous variable, the same five-point Likert scale was used.

c. Supply Chain Redefinition Practices (SCRED_PRAC)

This construct has had little prior research, especially in the context of SMEs. It aims to study the degree of implementation of disruptive environmental (SCRED_ENVIR) and social (SCRED_SOC) practices in SMEs, which implies the re-definition of the supply chain strategy (Marshall et al., 2014; Pagell, Mark and Wu, 2009). The first variable consists of 4 items, while the second of 7 items. The Likert scale is $(1=$ not considering it, $2=$ planning to consider it, $3=$ currently considering it, 4 = initiating implementation, 5 = implementing it successfully) (Zhu \& Sarkis, 2006).

d. Control variables

To reduce the possibility of obtaining spurious relationships, several control variables have been included in the statistical analysis: firm size expressed as the natural logarithm of the number of employees (LN_EMP), whether the firm possesses any certifications on quality or environmental management (CERTIF), and the economic sector (SECTOR).

\subsection{Data Analysis}

On the one hand, after organizing the data, missing cases were searched and the presence of atypical values was assessed (Hair et al., 2010). None of these two scenarios were found. On the other hand, based on the verified survey data, exploratory factor analysis (EFA) using SPSS ${ }^{\circledR}$ was applied to validate the theoretical constructs (factors). Later, we calculated pairwise correlation coefficients between the independent variables, finding low correlation values. Latent variables scores for the first and second order 
variables were calculated in LISREL®; the obtained scores are standardized, which means that each variables has a mean of zero and a standard deviation of one. Using these scores, a linear regression model was developed to assess the relationship between the level of stakeholder integration and the implementation of GSCM and disruptive practices, performing a separate regression for each type of key secondary stakeholder, as declared by the firms in the questionnaire.

\section{Results}

The EFA allowed validating two of the constructs in its original structure, i.e. GSCM practices (GSCM_PRAC) and stakeholder integration (STK_INT). With regard to GSCM_PRAC, all 25 items were valid and distributed into four factors (IEM_SME, ED_SME, GPURC_SME and CLIEN_SME), the way it was predicted from the literature review. The four factors extracted explain $74.21 \%$ of the total variance. In the case of STK_INT, the exercise yielded a reduction from 14 to 12 items organized in three factors (KNOW_STK, INT_STK and ADAP_SME), which explain $80.12 \%$ of the total variance.

In contrast, because SCRED_PRAC is a much less studied construct in the literature, and has not been validated in several studies, the results are different in comparison to the predicted model. This construct resulted in three factors extracted, which explain $71.98 \%$ of the total variance. These factors were renamed as SCRED_SOC, SCRED_ENVIR and SCRED_PRORES. The SCRED_PRORES factor comprises two items previously belonging to the construct SCRED_SOC, and related to product responsibility (SCRED_SOC1 y SCRED_SOC2) (see Appendix A).

Table 1 and Table 2 show the results of linear regression analysis. Regarding the GSCM_PRAC variable, statistically significant relationships between this and INT_STK (1\%), LN_EMP (10\%), SECTOR (5\%) and CERTIF (5\%) were found in MODEL 1 only. In the rest of models, the dependent variable does not have a relationship with the independent ones. Regarding the SCREAD_PRAC variable, in the first model, a statistically significant relationship was found between the dependent variable and INT_STK (5\%). In the second model, SCREAD_PRAC was found to have a statistically significant relationship with ONG (10\%) and CERTIF (10\%). And, in the third model, the same variable has statistically significant relationships with LN_EMP (1\%) and SECTOR $(5 \%)$.

Table 1. Results from Linear Regression of GSCM practices

\begin{tabular}{|l|c|c|c|c|}
\hline \multicolumn{5}{|c|}{ Dependent Variable: GSCM_PRAC } \\
\hline Independent Variables & $\begin{array}{c}\text { MODEL 1 } \\
(\text { COMMUN) }\end{array}$ & $\begin{array}{c}\text { MODEL 2 } \\
(\text { NGO) }\end{array}$ & $\begin{array}{c}\text { MODEL 3 } \\
\text { (KNOWL) }\end{array}$ & $\begin{array}{c}\text { MODEL 4 } \\
\text { (REGUL) }\end{array}$ \\
\hline CONSTANT & $-0,670^{*}$ & $-0,631$ & 0,678 & $-0,624$ \\
\hline INT_STK & $0,437 * * *$ & 0,551 & 0,180 & 0,169 \\
\hline LN_EMP & $0,210^{*}$ & 0,155 & $-0,335$ & 0,073 \\
\hline SECTOR & $-0,839^{* *}$ & 0,608 & 0,834 & 0,246 \\
\hline CERTIF & $0,740 * *$ & 1,283 & 0,623 & 0,126 \\
\hline $\mathrm{R}^{2}$ & 0,599 & 0,545 & 0,316 & 0,129 \\
\hline $\mathrm{N}$ & 26 & 9 & 22 & 38 \\
\hline
\end{tabular}


Table 2. Results from Linear Regression of sustainability-oriented innovations (supply chain strategy redefinition)

\begin{tabular}{|l|c|c|c|c|}
\hline \multicolumn{5}{|c|}{ Dependent Variable: SCREAD_PRAC } \\
\hline Independent Variables & $\begin{array}{c}\text { MODEL 1 } \\
\text { (COMMUN) }\end{array}$ & $\begin{array}{c}\text { MODEL 2 } \\
\text { (NGO) }\end{array}$ & $\begin{array}{c}\text { MODEL 3 } \\
\text { (KNOWL) }\end{array}$ & $\begin{array}{c}\text { MODEL 4 } \\
\text { (REGUL) }\end{array}$ \\
\hline CONSTANT & $-0,434$ & $-0,518$ & $1,746^{* * *}$ & $-0,843^{*}$ \\
\hline INT_STK & $0,420^{* *}$ & $0,699^{*}$ & 0,162 & 0,224 \\
\hline LN_EMP & 0,162 & $-0,033$ & $-0,693^{* * *}$ & 0,117 \\
\hline SECTOR & $-0,634$ & 0,882 & $1,306^{* *}$ & 0,052 \\
\hline CERTIF & 0,582 & $1,566^{*}$ & 0,092 & 0,173 \\
\hline $\mathrm{R}^{2}$ & 0,371 & 0,760 & 0,435 & 0,145 \\
\hline $\mathrm{N}$ & 26 & 9 & 22 & 38 \\
\hline
\end{tabular}

* Significant at 10\% ** Significant at 5\% *** Significant at 1\%

\section{Discussion}

The results from the linear regression models show evidence for the effect of SMEs' integration with the community on the extent of implementation of both GSCM and supply chain redefinition practices. This can be explained from the perspective of stakeholder integration as a process. Stakeholder integration starts with the acquisition of knowledge about the stakeholder and its demands; then, the company interacts/collaborates with its stakeholders; and, finally, the firm modifies its strategy and procedures to adapt to the stakeholder's demands (Plaza-Úbeda et al., 2010).

According to our linear regression results, the integration between the SMEs that interact with the community has a major influence on GSCM practices. This is similar to what was found in the literature regarding the influence of societal stakeholders. According to Doh \& Guay (2006), the influence of the neighboring community or environmental leaders on the firms' social and environmental behavior has been growing. Also, Sajjad, Eweje, \& Tappin (2015) conducted an exploratory case study and found that community and customers' expectations were highlighted as prime external triggers for SSCM implementation.

Likewise, several authors point out that product stewardship implies an organizational capacity not only to coordinate the functional groups within the firm, but to also integrate the perspective of key external stakeholders, such as environmentalists and community leaders (Betts, Wiengarten, \& Tadisina, 2015; Buysse \& Verbeke, 2003, Darnall, Henriques, \& Sadorsky, 2010, Delmas, 2009, Delmas \& Toffel, 2004, Neelam, Suresh, \& Sharma, 2014, Ni, 2012). Thus, the original relationship proposed by Stuart Hart in 1995 is supported by our results: "The companies that adopted product-stewardship strategies will evidence inclusion of external stakeholders in product-development and planning processes". For the group of firms that integrate with NGOs, the results provide some evidence for the effect of such integration on the implementation of sustainable practicesenvironmental and social-involving a redefinition of the supply chain strategy. Some authors have highlighted the importance of NGOs as drivers of environmental and social practices displayed by the firm internally and at its supply chain, in a direct or indirect form (Úbeda, de Burgos Jiménez, \& Ureña, 2011). These authors affirm that companies that adopt advanced environmental strategies usually establish collaboration 
with stakeholders such as the regulator and environmental NGOs in the construction of environmental standards or norms, and the establishment of voluntary agreements (Buysse et al., 2003).

The collaboration between enterprises and NGOs encourages environmental innovation, resulting in higher operational efficiency, as well as new technologies or new green products (Stafford et al., 2000). In the same way, this type of collaboration represents a knowledge source about creative ways to rethink operational activities, as well as addressing stakeholder concerns (Rondinelli and London, 2003). Collaboration with environmental NGOs can help enhance corporate green image (Hartman and Stafford, 1997; Kumar and Malegeant, 2006; Stafford and Hartman, 1996). Finally, Albino et al., (2012) showed that inter-organizational collaboration with NGOs is beneficial for a company's overall environmental performance, the management of its environmental footprint, and the environmental reputation of the company.

For the group of firms that integrate with the community, there is strong evidence for the positive effect of quality or environmental certifications on the implementation of GSCM, and some evidence for the effect of this same variable on the implementation of disruptive practices. The implementation of quality management systems or other voluntary schemes of certification is related with the adoption of green innovative activities, being more effective than public subsidies (Cuerva, Triguero, \& Córcoles, 2014). Moreover, the certification (e.g., in an Environmental Management System) is an external motivator for firms that are looking for best practices to follow (Daddi et al., 2016).

There was strong evidence suggesting that for the companies that see the regulator as their key stakeholder, this relationship does not have an effect in promoting GSCM and disruptive practices. This result can be explained from institutional theory, which considers the SME-regulatory dyad given by a coercive mechanism (Zhu, Sarkis and Lai, 2013). In contrast, for the company-community integration couple (Zhu, Sarkis, \& Lai, 2013) and the company-NGO (Sancha, Longoni, \& Giménez, 2015), the institutional mechanism is normative. In other words, the integration with the regulator functions as a coercive driver (Kauppi \& Hannibal, 2017) that leads to compliance with the norm, but does not explain the implementation of GSCM or disruptive sustainable practices. A previous study carried out in Colombia had shown that the friendlier the regulator policy style towards innovation is perceived, the greater the importance companies assign to the regulator's contribution to the solution of their environmental problems (MorenoMantilla, 2007). Our results could then indicate that the policy style of the regulator in Colombia does not favor eco-innovation, at least at the SMEs level.

\section{Conclusions}

This research attempted to answer whether SMEs' integration with secondary stakeholders influences the implementation of sustainable practices in the supply chain, for the context of an emerging economy. The study followed a web survey strategy for data collection and data analysis was developed through exploratory factor analysis (EFA) and linear regression methods. We found strong evidence for the effect of Colombian SMEs' integration with the community on the implementation of both 
GSCM practices and sustainable practices involving a redefinition of the supply chain strategy. There is also some evidence for the effect of NGOs-SMEs integration on the implementation of disruptive sustainable practices. However, we found no evidence that integration with the regulator influences the development of any of these types of practices.

One of the contributions to the literature is our finding that the integration with the community has a positive effect on the implementation of GSCM practices and disruptive innovations, in the context of an emerging economy. In particular, regarding disruptive sustainable practices, sufficient support for such relationship has not been found in the SMEs innovation literature. Therefore, it is necessary to deepen the investigation of why and how integrating with the community generates an effect on the development of sustainable disruptive practices in SMEs. From our study, we can propose that this type of relationship is instrumental in order to implement practices such as local sourcing, fair trade, inclusive business, or close loop supply chain. This implies that the company makes the neighboring community part of its supply chain, for instance through the implementation of supplier development programs when its suppliers are constituted by community members.

Another contribution to the literature is the evidence regarding the influence of the NGO-SMEs dyad in deployment of supply chain redefinition practices. The literature so far focused on how integration encourages environmental innovation, but of a more incremental nature. Again, it is necessary to analyze more deeply how integration with NGOs affects the development of this type of practices, through the analysis of mechanisms such as inter-organizational transfer of knowledge.

With respect to contributions to practice, the results of this research can serve as a guide for entities such as the government or NGOs to design their policies aimed at linking Colombian SMEs in networks and alliances that promote sustainable development, not only to comply with international and local standards, but also to jointly design new sustainable innovations that go beyond the continuous improvement approach.

A limitation of this research is that moderating or mediating effects that may affect the relationship under study were not considered. Recent research in business management assumes that it is unlikely that performance relationships of environmental protection practices can be explained with a single model (Aragón-Correa \& A. Rubio-López, 2007; López-Gamero, Molina-Azorín, \& Claver-Cortés, 2009; Wagner, 2007). Thus, the incorporation of contingent factors endogenous or exogenous to the SMEs is recommended for future works.

Another limitation of our study has to do with the conceptualization of relationships. As most previous studies, following stakeholder theory, to better understand how value is created and distributed, we adopted as unit of analysis the dyadic relationship between a SME and the key stakeholder. However, to better describe how organizations respond to stakeholders, the multiple and interdependent interactions that simultaneously exist in stakeholder environments must be considered (Fliaster \& Kolloch, 2017). Following Fliaster \& Kolloch (2017, p. 4), we believe that future research should then focus on exploring the impact of network ties of primary and secondary stakeholders on the implementation of sustainable innovations. For instance, SMEs with simultaneous evidence of development of advanced sustainable practices and integration with non- 
economic stakeholders could be studied using a multiple case study strategy.

\section{References}

Albino, V., Maria, R., \& Pontrandolfo, P. (2012). Do inter-organizational collaborations enhance a fi rm 's environmental performance? a study of the largest U . S . companies. Journal of Cleaner Production, 37, 304-315. https://doi.org/10.1016/j.jclepro.2012.07.033

Aragón-Correa, J. A., \& A. Rubio-López, E. (2007). Proactive Corporate Environmental Strategies: Myths and Misunderstandings. Long Range Planning, 40(3), 357-381. https://doi.org/10.1016/j.lrp.2007.02.008

Aragón-Correa, J. A., Hurtado-Torres, N., Sharma, S., \& García-Morales, V. J. (2008). Environmental strategy and performance in small firms: A resource-based perspective. Journal of Environmental Management, 86(1), 88-103. https://doi.org/10.1016/j.jenvman.2006.11.022

Aragón Correa, J. A., Hurtado Torres, N. E., \& García Morales, V. J. (2005). Un modelo explicativo de las estrategias medioambientales avanzadas para pequeñas y medianas empresas y su influencia en los resultados. Cuadernos de Economía Y Dirección de La Empresa, (25), 29-52. Retrieved from http: $/ /$ dialnet.unirioja.es $/$ servlet/articulo?codigo $=2162950 \&$ info $=$ resumen\&idioma $=$ SPA

Betts, T. K., Wiengarten, F., \& Tadisina, S. K. (2015). Exploring the impact of stakeholder pressure on environmental management strategies at the plant level: What does industry have to do with it? Journal of Cleaner Production, 92, 282-294. https://doi.org/10.1016/j.jclepro.2015.01.002

Bianchi, R. (1998). "Greening " SMEs â€TM Competitiveness, 269-281. Retrieved from https://linkspringer-com.ezproxy.unal.edu.co/article/10.1023/A\%7B\%25\%7D3A1007980420087

Bos-Brouwers, H. E. J. (2010a). Corporate sustainability and innovation in SMEs: Evidence of themes and activities in practice. Business Strategy and the Environment, 19(7), 417-435. https://doi.org/10.1002/bse.652

Bos-Brouwers, H. E. J. (2010b). Corporate sustainability and innovation in SMEs: Evidence of themes and activities in practice. Business Strategy and the Environment, 19(7), 417-435. https://doi.org/10.1002/bse.652

Buysse, K., \& Verbeke, A. (2003). Proactive environmental strategies: A stakeholder management perspective. Strategic Management Journal, 24(5), 453-470. https://doi.org/10.1002/smj.299

Buysse, K., Verbeke, A., Strategic, S., Journal, M., May, N., Wiley, J., ... Verbeke, A. (2003). Proactive Environmental Strategies: a Management Perspective Stakeholder. Strategic Management Journal, 24(5), 453-470.

Cainelli, G., De Marchi, V., \& Grandinetti, R. (2015). Does the development of environmental innovation require different resources? Evidence from Spanish manufacturing firms. Journal of Cleaner Production, 94, 211-220. https://doi.org/10.1016/j.jclepro.2015.02.008

Carter, C. R., \& Rogers, D. S. (2008). A framework of sustainable supply chain management: moving toward new theory. International Journal of Physical Distribution \& Logistics Management, 38(5), 360-387.

Chen, L., Zhao, X., Tang, O., Price, L., Zhang, S., \& Zhu, W. (2017). Supply chain collaboration for sustainability: A literature review and future research agenda. International Journal of Production Economics, 194(March), 73-87. https://doi.org/10.1016/j.ijpe.2017.04.005

Chin, T. A., Tat, H. H., \& Sulaiman, Z. (2015). Green supply chain management, environmental collaboration and sustainability performance. Procedia CIRP, 26, 695-699. https://doi.org/10.1016/j.procir.2014.07.035

Creswell, J. (2005). Educational research: Plannig, conducting, and evaluating quantitative and qualitative research (2a). Upper Saddle River: Pearson Education Inc.

Cuerva, M. C., Triguero, Á., \& Córcoles, D. (2014). Drivers of green and non-green innovation: Empirical evidence in Low-Tech SMEs. Journal of Cleaner Production, 68, 104-113. https://doi.org/10.1016/j.jclepro.2013.10.049

Darnall, N., Henriques, I., \& Sadorsky, P. (2010). Adopting proactive environmental strategy: The influence of stakeholders and firm size. Journal of Management Studies, 47(6), 1072-1094. https://doi.org/10.1111/j.1467-6486.2009.00873.x 
de Jesus Pacheco, D. A., ten Caten, C. S., Jung, C. F., Ribeiro, J. L. D., Navas, H. V. G., \& Cruz-Machado, V. A. (2016). Eco-innovation determinants in manufacturing SMEs: Systematic review and research directions. Journal of Cleaner Production, 142. https://doi.org/10.1016/j.jclepro.2016.11.049

de Lange, D. E. (2010). An overview of the green international management literature. Research Companion To Green International Management Studies: A Guide for Future Research, Collaboration and Review Writing, (1), 10-46.

De Maesschalck, R., Jouan-Rimbaud, D., \& Massart, D. L. (2000). The mahalanobis distance. Chemometrics and Intelligent Laboratory Systems, 50(1), 1-18.

De Marchi, V. (2012). Environmental innovation and R\&D cooperation: Empirical evidence from Spanish manufacturing firms. Research Policy, 41(3), 614-623. https://doi.org/10.1016/j.respol.2011.10.002

del Brío, J. Á., \& Junquera, B. (2003). A review of the literature on environmental innovation management in SMEs: implications for public policies. Technovation, 23(12), 939-948. https://doi.org/10.1016/S0166-4972(02)00036-6

Delmas, M. (2009). Stakeholders and Competitive Advantage: the Case of Iso 14001. Production and Operations Management, 10(3), 343-358. https://doi.org/10.1111/j.1937-5956.2001.tb00379.x

Delmas, M., \& Toffel, M. (2004). Stakeholders and environmental management practices: an institutional framework. Business Strategy and the Environment, 13(May), 209-222.

Diabat, A., Kannan, D., \& Mathiyazhagan, K. (2014). Analysis of enablers for implementation of sustainable supply chain management - A textile case. Journal of Cleaner Production, 83, 391-403. https://doi.org/10.1016/j.jclepro.2014.06.081

Fliaster, A., \& Kolloch, M. (2017). Implementation of green innovations - The impact of stakeholders and their network relations. R and D Management, 1-12. https://doi.org/10.1111/radm.12257

Forza, C. (2002). Survey research in operations management. International Journal of Operations and Production Management, 22(2), 152-194. https://doi.org/10.1108/01443570210414310

Gandhi, S., Mangla, S. K., Kumar, P., \& Kumar, D. (2015). Evaluating factors in implementation of successful green supply chain management using DEMATEL: A case study. International Strategic Management Review, 3(1), 96-109. https://doi.org/10.1016/j.ism.2015.05.001

Gerstenfeld, A., \& Roberts, H. (2000). Size matters: barriers and prospects for environmental management in small and medium-sized enterprises. Small and Medium-Sized Enterprises and the Environment, 106119.

Ghisetti, C., \& Pontoni, F. (2015). Investigating policy and R\&D effects on environmental innovation: A meta-analysis. Ecological Economics. https://doi.org/10.1016/j.ecolecon.2015.07.009

Gold, S., Seuring, S., \& Beske, P. (2010). Sustainable supply chain management and inter-organizational resources: a literature review. Corporate Social Responsibility and Environmental Management, 17(4), 230-245.

Green Jr, K. W., Zelbst, P. J., Meacham, J., \& Bhadauria, V. S. (2012). Green supply chain management practices: impact on performance. Supply Chain Management: An International Journal, 17(3), 290-305. https://doi.org/10.1108/13598541211227126

Gunasekaran, A., Subramanian, N., \& Rahman, S. (2015). Green supply chain collaboration and incentives: Current trends and future directions. Transportation Research Part E: Logistics and Transportation Review, 74, 1-10. https://doi.org/10.1016/j.tre.2015.01.002

Hair, J. F., Black, W. C., Babin, B. J., \& Anderson, R. E. (2010). Multivariate data analysis (7th ed.) (Upper Sadd). NJ: Prentice Hall.

Hart. (1995a). A Natural-Resource-Based View of the Firm. Academy of Management Review, 20(4), 986-1014.

Hart, S. L. (1995b). a Natural-Resource-Based View of the Firm. Academy of Management Review, 20(4), 9861014. https://doi.org/10.5465/AMR.1995.9512280033

Hart, S. L., \& Dowell, G. (2011). A Natural-Resource-Based View of the Firm : Fifteen Years After, 37(5), 1464-1479. https://doi.org/10.1177/0149206310390219

Hart, S. L., \& Sharma, S. (2004). Engaging Fringe Stakeholders for Competitive Imagination. Academy of Management Executive, 18(1), 7-18. https://doi.org/10.2307/4166031

Hojnik, J., \& Ruzzier, M. (2016). What drives eco-innovation? A review of an emerging literature. Environmental Innovation and Societal Transitions, 19, 31-41. https://doi.org/10.1016/j.eist.2015.09.006

Imle, M., \& Atwood, J. (1988). Retaining qualitative validity while gaining quantitative reliabitlity and validity.pdf. 
Khalili, N. R., Duecker, S., Ashton, W., \& Chavez, F. (2015). From cleaner production to sustainable development: The role of academia. Journal of Cleaner Production, 96, 30-43. https://doi.org/10.1016/j.jclepro.2014.01.099

Klewitz, J., \& Hansen, E. G. (2014). Sustainability-oriented innovation of SMEs: a systematic review. Journal of Cleaner Production, 65, 57-75. https://doi.org/10.1016/j.jclepro.2013.07.017

Klewitz, J., \& Hansen, E. G. (2014). Sustainability-oriented innovation of SMEs: A systematic review. Journal of Cleaner Production, 65, 57-75. https://doi.org/10.1016/j.jclepro.2013.07.017

Knight, P., \& Jenkins, J. O. (2009). Adopting and applying eco-design techniques: a practitioners perspective. Journal of Cleaner Production, 17, 549-558. https://doi.org/10.1016/j.jclepro.2008.10.002

Lawrence, S. R., Collins, E., Pavlovich, K., \& Arunachalam, M. (2006). Sustainability practices of SMEs: The case of NZ. Business Strategy and the Environment, 15(4), 242-257. https://doi.org/10.1002/bse.533

López-Gamero, M. D., Molina-Azorín, J. F., \& Claver-Cortés, E. (2009). The whole relationship between environmental variables and firm performance: Competitive advantage and firm resources as mediator variables. Journal of Environmental Management, 90(10), 3110-3121. https://doi.org/10.1016/j.jenvman.2009.05.007

Mainardes, E. W., Alves, H., \& Raposo, M. (2011). Stakeholder theory: issues to resolve. Management Decision, 49(2), 226-252. https://doi.org/10.1108/00251741111109133

Marshall, D., McCarthy, L., Heavey, C., \& McGrath, P. (2014). Environmental and social supply chain management sustainability practices: construct development and measurement. Production Planning \& Control: The Management of Operations, 1-18. https://doi.org/10.1080/09537287.2014.963726

Mir, D. F., \& Feitelson, E. (2007). Factors affecting environmental behavior in micro-enterprises laundry and motor vehicle repair firms in Jerusalem. International Small Business Journal, 25(4), 383-415.

Moreno-Mantilla, C. (2007). Adopción de tecnologías más limpias en firmas industriales: Un estudio multimétodo sobre el efecto de la aplicación de límites de vertimiento y tasas retributivas en Santander, Colombia. Cuadernos de Administración, 20(33), 49-78.

Neelam, S., Suresh, J., \& Sharma, P. (2014). Determinants of proactive environmental management practices in Indian firms: an empirical study. Journal of Cleaner Production, 66, 469-478.

$\mathrm{Ni}, \mathrm{Y}$. A. (2012). Estudio de la influencia de los stakeholders en la implementación de sistemas de logística reversa. Caso de la industria del plástico en Bogotá D.C. (Colombia).

Oelze, N., Hoejmose, S. U., Habisch, A., \& Millington, A. (2016). Sustainable development in supply chain management: the role of organizational learning for policy implementation. Business Strategy and the Environment, 25(4), 241-260.

Pagell, Mark and Wu, Z. (2009). Building a More Complete Theory of Sustainable Supply Chain Management Using Case Studies of 10 Exemplars, (April), 37-56. https://doi.org/10.1111/j.1745-493X.2009.03162.x

Pagell, M., \& Shevchenko, A. (2014). Why research in sustainable supply chain management should have no future. Journal of Supply Chain Management, 50(1), 44-55. https://doi.org/10.1111/jscm.12037

Parrish, B. D., \& Foxon, T. J. (2006). Sustainability entrepreneurship and equitable transitions to a lowcarbon economy. Greener Management International, (55), 47.

Perkmann, M., \& Walsh, K. (2007). University-industry relationships and open innovation: Towards a research agenda. International Journal of Management Reviews, 9(4), 259-280. https://doi.org/10.1111/j.1468-2370.2007.00225.x

Plaza-Úbeda, J. A., de Burgos-Jiménez, J., \& Carmona-Moreno, E. (2010). Measuring stakeholder integration: Knowledge, interaction and adaptational behavior dimensions. Journal of Business Ethics, 93(3), 419-442. https://doi.org/10.1007/s10551-009-0231-9

Polit, D. F., Beck, C. T., \& Owen, S. V. (2007). Is the CVI an Acceptable Indicator of Content Validity? Appraisal and Recommendations. Research in Nursing \& Health, 30(4), 459-467. https://doi.org/10.1002/nur

Rodgers, C. (2010). Sustainable entrepreneurship in SMEs: A case study analysis. Corporate Social Responsibility and Environmental Management, 17(3), 125-132. https://doi.org/10.1002/csr.223

Rodriguez, J. A., \& Wiengarten, F. (2017). The role of process innovativeness in the development of environmental innovativeness capability. Journal of Cleaner Production, 142, 2423-2434. https://doi.org/10.1016/j.jclepro.2016.11.033

Rondinelli, D. A., \& London, T. (2003). How corporations and environmental groups cooperate: assessing cross-sectoral alliances and collaborations. Academy of Management Executive, 17, 61--76. 
Sajjad, A., Eweje, G., \& Tappin, D. (2015). Sustainable Supply Chain Management: Motivators and Barriers. Business Strategy and the Environment, 24(7), 643-655. https://doi.org/10.1002/bse.1898

Schaltegger, S., \& Wagner, M. (2011). Sustainable entrepreneurship and sustainability innovation: categories and interactions. Bus. Strat. Environ., 20, 222-237.

Schöggl, J.-P., Fritz, M. M. C., \& Baumgartner, R. J. (2016). Toward supply chain-wide sustainability assessment: Part 1 - a conceptual framework and an aggregation method to assess supply chain performance. Journal of Cleaner Production, 131, 822-835. https://doi.org/10.1016/j.jclepro.2016.04.035

Seuring, S., \& Müller, M. (2008). From a literature review to a conceptual framework for sustainable supply chain management. Journal of Cleaner Production, 16(15), 1699-1710. https://doi.org/10.1016/j.jclepro.2008.04.020

Sharma, S., \& Vredenburg, H. (1998). Proactive corporate environmental strategy and the development of competitively valuable organizational capabilities. Strategic Management Journal, 19(8), 729-753. https://doi.org/10.1002/(SICI)1097-0266(199808)19:8<729::AID-SMJ967>3.0.CO;2-4

Srivastava, S. K. (2007). Green supply-chain management: A state-of-the-art literature review. International Journal of Management Reviews, 9(1), 53-80. https://doi.org/10.1111/j.1468-2370.2007.00202.x

Sroufe, R., Curkovic, S., Montabon, F., \& Melnyk, S. A. (2000). The new product design process and design for environment: "Crossing the chasm." International Journal of Operations \& Production Management, 20(2), 267-291.

Tamayo Orbegozo, U., Vicente Molina, M.-A., \& Villarreal Larrinaga, O. (2016). Eco-innovation strategic model. A multiple-case study from a highly eco-innovative European region. Journal of Cleaner Production, 142, 1347-1367. https://doi.org/10.1016/j.jclepro.2016.11.174

Testa, F., \& Iraldo, F. (2010). Shadows and lights of GSCM (green supply chain management): Determinants and effects of these practices based on a multi-national study. Journal of Cleaner Production, 18(1011), 953-962. https://doi.org/10.1016/j.jclepro.2010.03.005

Touboulic, A., Walker, H. L., Barlow, J., \& Pettigrew, M. (2011). Theoretical perspectives on sustainable supply chain management: a review of the literature.

Ubeda, J. A. P., de Burgos Jiménez, J., \& Ure??a, L. J. B. (2011). Grupos de interés, gestión ambiental y resultado empresarial: Una propuesta integradora. Cuadernos de Economia Y Direccion de La Empresa, 14(3), 151-161. https://doi.org/10.1016/j.cede.2011.02.001

Vachon, S., \& Klassen, R. D. (2006). Extending green practices across the supply chain. International Journal of Operations \& Production Management, 26(7), 795-821. https://doi.org/10.1108/01443570610672248

Vachon, S., \& Klassen, R. D. (2008). Environmental management and manufacturing performance: The role of collaboration in the supply chain. International Journal of Production Economics, 111(2), 299-315. https://doi.org/10.1016/j.ijpe.2006.11.030

Vagias, W. (2006). Likert-type scale response anchors. Clemson International Institute for Tourism and ..., 3-4. https://doi.org/10.1525/auk.2008.125.1.225

Wagner, M. (2007). On the relationship between environmental management, environmental innovation and patenting: Evidence from German manufacturing firms. Research Policy, 36(10), 1587-1602. https://doi.org/10.1016/j.respol.2007.08.004

Zhu, Q., \& Sarkis, J. (2006). An inter-sectoral comparison of green supply chain management in China: Drivers and practices. Journal of Cleaner Production, 14(5), 472-486. https://doi.org/10.1016/j.jclepro.2005.01.003

Zhu, Q., Sarkis, J., \& Lai, K. hung. (2008). Green supply chain management implications for "closing the loop." Transportation Research Part E: Logistics and Transportation Review, 44(1), 1-18. https://doi.org/10.1016/j.tre.2006.06.003 